\title{
THE STRATEGIC ENTREPRENEURIAL THINKING IMPERATIVE
}

\author{
S Dhliwayo, Dept of Entrepreneurship, University of Johannesburg, South Africa \& JJ van \\ Vuuren, Dept of Business Management, University of Pretoria, South Africa
}

Purpose: The aim of this paper is to demonstrate that strategic entrepreneurial thinking is a unitary concept which should be viewed as a standalone construct.

Design/Methodology/Approach: The concept strategic entrepreneurial thinking is modelled from an analysis of strategic thinking and entrepreneurial thinking from available literature. The strategic entrepreneurial mindset imperative is then emphasised and confirmed.

Findings: This paper's finding is that there is no difference between strategic thinking and the entrepreneurial mindset. Instead, the composite strategic entrepreneurial mindset construct should be treated as a unitary construct.

Practical implications: The importance for practitioners is that the paper integrates two constructs, strategic thinking and entrepreneurial thinking into a new concept, strategic entrepreneurial thinking. The paper shows how difficult it is to split this thinking and behaviour into separate strategic and entrepreneurial thought and action processes.

Originality/value: The paper explores the "thinking" aspect of the strategic entrepreneurial concept which prominent authors on the strategic entrepreneurship topic seem to have not focused on. The resultant strategic entrepreneurial mindset is modelled into a new stand alone concept on its own.

Key words and phrases: Strategy, entrepreneurial thinking, entrepreneurial mindset

\section{INTRODUCTION}

Strategic thinking is usually associated with the competitiveness of the organisation, while entrepreneurial thinking is associated with innovation and creativity to capture opportunities. Strategic thinking is usually isolated as the "thinking" part of the strategic planning process. This wrongly implies the removal of the behavioural or "action" component of strategy thinking from the construct. Strategic thinking, just like the entrepreneurial thinking, is a mindset that encapsulates thinking, state of mind and way of behaviour.

The concept of strategic entrepreneurship has widely been written about primarily as a relationship between strategic management and corporate entrepreneurship. Prominent authors who have written on the concept include: Wickham (2001); Meyer, Neck and Meeks (2002), McGrath and MacMillan (2000); Sathe (2003); Antonic and Hisrich (2001, 2003, 2004); Hitt, Ireland, Camp and Sexton (2002); and Morris and Kuratko (2002). These writings have given birth to terms such as strategic entrepreneurial management, entrepreneurial strategies and strategic entrepreneurial planning, but none seems to have concentrated on the mindset, the "thinking" aspect of any of these broad terms.

This paper discusses the same strategic entrepreneurship concept as expounded and developed by these authors but with a specific focus on the "mindset" or "thinking" aspect. It provides a model which shows that, when strategic thinking and entrepreneurial thinking are practiced by an individual / organisation, a new concept - strategic entrepreneurial thinking - is born. This new concept is unitary and should be viewed as a standalone construct.

The interest in the study of strategic and entrepreneurial thinking is necessitated by today's rapidly changing business environment that is about speed and action. All business regardless of size and age must be entrepreneurial to effectively compete and survive (Meyer 
et al., 2002:19). In addition, Schendel (1995:145), Slater and Olson (2000:813) and Meyer et al. (2002:27) discuss what they term the "entrepreneurial" and the "integrative" components of strategy. They argue that the components determine how businesses achieve competitive advantage.

This is a concept paper. It gives an overview of the entrepreneurial mindset as well as strategic thinking and then focuses on the strategic entrepreneurial mindset showing how this has developed into a standalone concept. The paper proposes that strategic thinking is not different from entrepreneurial thinking. This is because the key dimensions/elements of strategic thinking and entrepreneurial thinking are the same, resulting in the term strategic entrepreneurial thinking. The "thinking" is not exclusive of behaviour.

When entrepreneurial actions are the foundation on which an organisation's strategy is built, an entrepreneurial strategy is being implemented. The terms" mindset" and "thinking" are used interchangeably in this article.

The paper provides the research problem first. This is followed by the literature review, which explores the concepts of the entrepreneurial and strategic mindsets. The strategic entrepreneurial thinking model is then developed. Suggestions on how to cultivate the strategic entrepreneurial thinking is provided before concluding.

\section{RESEARCH PROBLEM}

Prominent authors have widely written on the concept of strategic entrepreneurship primarily as a relationship between strategic management and corporate entrepreneurship. However, none seems to have concentrated on the "mindset": the "thinking" aspect of strategic entrepreneurship.

When strategic thinking and entrepreneurial thinking are practiced by an individual/ organisation, a new concept - strategic entrepreneurial thinking, a unitary construct - is born. This is based on this paper's proposition that strategic thinking is not different from entrepreneurial thinking.

\section{LITERATURE REVIEW}

The paper will explore what the elements of entrepreneurial mindset are. It also explores the concept of strategic thinking and then develops the strategic entrepreneurial thinking proposition.

\section{THE ENTREPRENEURIAL MINDSET}

An entrepreneurial mindset denotes a way of thinking and action about business and its opportunities that captures the benefits of uncertainty. Strategic entrepreneurship is the integration of entrepreneurial (opportunity seeking actions) and strategic (advantage seeking actions) perspectives to design and implement entrepreneurial strategies that create wealth (Sathe, 2000:2).

This need for an entrepreneurial mindset is vital because, as Bouchard (2001:3) emphasises, entrepreneurship is exposed to the liabilities of the new and to failure because the entrepreneurial process is complex and uncertain.

As pointed out by Morris and Kuratko (2002:150), the contemporary business environment is characterised by increasing risk, decreased ability to forecast, and fluid industry boundaries that need an entrepreneurial mindset that must unlearn traditional management principles in order to minimise failure.

This mindset needs to create or help shape its own environment by creating a strategic and entrepreneurial alertness for it to survive the chaos, complexity and contradictions. 
Organisations should focus on the entrepreneurial mindset when reviewing strategy because this is a way of thinking about the business that captures the benefits of uncertainty (McGrath \& Macmillan, 2000:1).

Hitt et al. (2002:6) note that entrepreneurial organisations create new resources or obtain and combine existing resources in unique ways to invent and innovate. The ability to take advantage of munificent settings and survive the hostile environments is what being entrepreneurial is about.

Entrepreneuring is a mindset and behaviour. It is the sum of an organisation's learning, innovation, renewal and venturing activities (Antonic \& Hisrich, 2003:13). This entrepreneurial mindset enables the championing of new initiatives in established organisations to make some material difference by coming up with new valuable ideas which are resourced and developed in an encouraging, enabling culture (Thompson, 2004:245).

Meyer and Happard (2000:2) talk of an entrepreneurial dominant logic which, they argue, leads a firm and its members to constantly search and filter information for new product ideas and process innovations leading to greater profitability.

Speed in decision-making and fresh insights are important by-products of the entrepreneurial mindset and, by having this mindset, entrepreneurs are able to effectively deal with a wide array of problems and irregularities inherent in developing new opportunities (Wright et al., 2001:114).

The entrepreneurial mindset is one of belief in change and innovation while recognising and developing the capabilities to achieve such change (Morris \& Kuratko, 2002:96).

McGrath and MacMillan (2000) cited in Morris and Kuratko (2002:97) outline some of the characteristics of the entrepreneurial mindset as follows:

- Passionately seeking new opportunities.

- Pursues opportunities with enormous discipline.

- Pursues only the best opportunities and tightly link their strategy with the choice of projects

- Focus on execution, specifically adaptive execution when the best way to exploit it evolves.

- Engages the energies of everyone in their domain (internally and externally).

The entrepreneurial mindset is about creativity, innovation and opportunity taking that result in organisational wealth creation and success. Such a mindset allows entrepreneurs to make convincing decisions in the face of uncertainty.

The paper proposes that: Strategic thinking is not different from entrepreneurial thinking.

A study by Antonic and Hisrich (2003:15) identifies the characteristic dimensions of entrepreneurship as the following: business venturing; creativity; risk taking; proactiveness; innovativeness; strategic renewal; autonomy; and competitive aggressiveness. An entrepreneurial mindset or entrepreneurial thinking therefore encompasses the generation and activation of these behaviours.

The above dimensions are identified and compared to dimensions of strategic thinking in the analysis of strategic thinking that follow. This is done to show the similarities between the dimensions thereby supporting the above proposition. The discussion is also reflected in Figure 1. 


\section{STRATEGIC THINKING}

Strategic thinking is a way of solving problems that combines the rational and convergent approaches with creative and divergent thought processes and is intertwined with ongoing action processes, (Bonn, 2005:338; Ratcliffe, 2006:40; Mintzberg, Ahlstrand \& Lampel, 1998:42 and Masifern \& Vila, 1998:16).

According to Abraham (2005:5), strategic thinking is the process of finding alternative viable strategies or business models of competing or delivering customer value that is done as part of the strategic planning process. Its challenge is to find a different way to do what the organisation now does or to adopt a business model different from its competitors. This is "finding your own race to run and win it". It is about "walking in your customer's shoes", spotting where value lies then organising to deliver it. This translates to a common definition of entrepreneurial thinking: ability for opportunity identification, satisfaction of needs and creation of value.

"Organising to deliver" equates to mobilisation/combining of resources to create and deliver value.

This approach to strategic thinking is multi-dimensional, integrating the micro-domain's focus on individuals and groups with the macro-domain's focus on: organisations and their context (Bonn, 2001:63, 2005:340); futures thinking; scenario thinking and creativity (Ratcliffe, 2005:48); and learning (Senge, 1996).

The role of strategic thinking is to seek innovation and imagine new and very different futures that may lead a company to redefine its core strategies and even its industry (Graetz, 2000: 457).

Innovation and redefinition of one's strategies and industry is part of the entrepreneurial mindset. This is what Antonic and Hisrich, citing Zahra (1993) and Guth and Ginsberg (1990), refer to as strategic renewal.

The ability to think strategically in the strategy-making process recognises that strategic thinking and planning are "distinct but interrelated and complementary thought processes" that must sustain and support each other for effective strategic management. As integral components of strategic management there is a need for moments of convergence and moments of divergence, a synergistic tension that reconciles creativity with rationalism and pragmatism and blends synthetic with analytical critical thinking (Graetz, 2002:460).

Strategy is about ideas and the development of novel solutions to create competitive advantage. Strategic thinkers must search for new approaches and envision better ways of doing things, a perquisite of which is creativity. Creativity is needed to imagine multiple possibilities and to search for alternatives to conventional approaches (Bonn, 2001:65).

Strategic planning, whose aim is "to do better what a firm already does well", takes place within familiar contexts, can capitalise on past experience and can apply proven recipes. It is less expressed to failure than entrepreneurship and is characterised by a marked "anti-failure bias" (Bouchard, 2001:3). This is the "adaptive execution when best way to exploit evolves" earlier cited in Morris and Kuratko (2002).

Novelty and creativity are key elements of entrepreneurial thinking, Miller and Friesen (1983) and Knight (1977), cited in Antonic and Hisrich (2003:15).

Fink et al. (2005:360) point out that, to survive and grow in an era of continuous change, organisations must identify upcoming opportunities and threats early enough and address them in their strategic planning through strategic thinking. This equates to proactiveness in entrepreneurial thinking. 
Organisations that encourage a wide range of different ideas and views are more likely to produce plans that are comprehensive and fully developed. Thinking is a skill and, as is the case with most skills, it can be developed through training and practice. Employees should be provided with training necessary to develop strategic thinking skills and given the opportunity to practice those skills in their work environment. In addition, they should be rewarded for thinking strategically when developing their plans (Lewis et al., 2001:138). This equates to "engaging the energies of everyone" as expounded by McGrath and MacMillan (2000).

Technology is about allowing more for less and more in less time. The process of information gathering and decision-making based on available information and action based on the decision made has been compressed to the point of being virtually being "real-time". This real time demands responsiveness, speed, quick strategic thinking and planning, and the capacity to break down bureaucratic slowness (Meyer et al., 2003:31).

Skrt and Antonic (2004:107) note that strategic thinking has become a must for all entrepreneurs in the time of global competition, technological change and increased dynamics in markets. They quote Stevenson et al. (1998) Hisrich and Peters (2001) and Timmons and Spinelli (2003) in support.

Strategic thinking requires a holistic approach and attention to the underlying structures of complex situations and thinking that enables reconciliation of apparent contradictions and the development of alternative solutions. A holistic view requires recognition that organisations are components within large and complex systems, such as markets, industries and nations (Bonn, 2001:65).

This holistic approach, when combined with opportunity seeking and exploitative behaviour, results in a strategic entrepreneurial mindset. This thinking is crucial to organisational success (Wunderer 2001:193), competitiveness (Zahra \& Bogna, 2000:135), growth (O'Gormon, 2001:64), value creation and profitability (Covin \& Slevin, 2002:310).

\section{THE STRATEGIC ENTREPRENEURIAL THINKING IMPERATIVE}

Strategic entrepreneurial thinking is a unitary thinking and behavioural process. It is difficult if not impossible to separate this single process into independent component processes of strategic thinking and entrepreneurial thinking.

Hitt et al. (2002:28) set out the content domain that lay at the center of entrepreneurship and strategic planning as innovation, organisational networks, internationalisation, organisational learning, teams, growth, flexibility and change. It is the integration between the two that results in fast growing firms.

Meyer et al. (2002:29) urge the integration or blend into a whole of the two constructs as a single field for the following reasons:

- Both constructs view firm performance as a primary dependant variable.

- The new economy and the increasingly dynamic nature of the competitive environment demand entrepreneurial qualities such as flexibility and real time responsiveness.

- Shifting paradigms in strategic management highlight the dynamic nature of organisations and the need for all organisations to be entrepreneurial. 


\section{Figure 1: The strategic entrepreneurial mindset model}

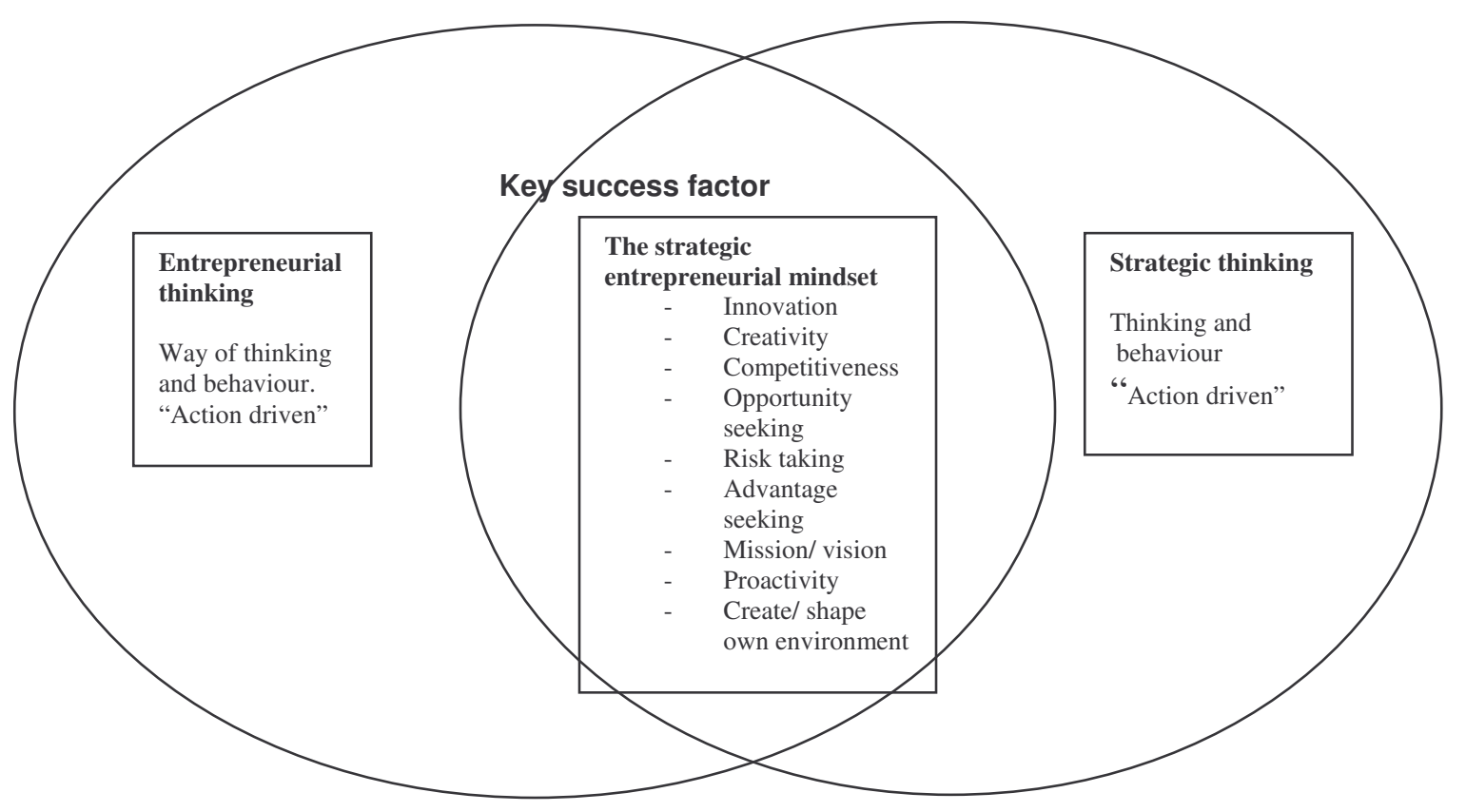

Source adapted from: Sathe (2003); Antonic \& Hisrich (2003) and Hitt et al. (2002).

The strategic entrepreneurial mindset model, reflected in Figure 1 above, clearly shows the key dimensions of strategic thinking as well as those of entrepreneurial thinking. These dimensions define the strategic entrepreneurial mindset. The strategic entrepreneurial mindset is a key success factor without which a business will not succeed.

According to Michael et al. (2002:48), an entrepreneurial mindset focuses on value creation, opportunity seeking, recognition, or discovering tomorrow's business today.

Strategic entrepreneurship is the integration of entrepreneurial (opportunity seeking actions) and strategic (advantage seeking actions) perspectives to design and implement entrepreneurial strategies that create wealth (Sathe, 2003:2).

Sathe (2003) further points out that strategy provides a starting point for the examination of corporate entrepreneurship where core competences of a corporation can be leveraged to create new businesses.

Hitt et al. (2002:2) notes that strategic entrepreneurship is entrepreneurial action that is taken with a strategic perspective and that the entrepreneurial and strategic actions are complementary and can achieve the greatest wealth when integrated.

Organisations that continuously focus on finding better solutions maintain competitive advantage and they do so through effective strategic thinking and entrepreneurial thinking throughout the ranks of the organisation (Lewis et al., 2001:149).

The entrepreneurial mindset provides an organisation with opportunities to connect with its strategic vision or shape its strategic future. This is what Kelly et al. (2002:1) refer to as part of strategic visioning / thinking.

An entrepreneurial mindset denotes a way of thinking about business and its opportunities that capture the benefits of uncertainty. These benefits are captured as individuals search for and attempt to exploit high potential opportunities that are associated with uncertain business 
environments. These entrepreneurial and strategic actions should be integrated in order to create maximum wealth. They should be complementary and not interchangeable (Hitt et al., 2002:2).

The fit between entrepreneurial orientation as a strategic element and its organisation and environmental contexts may have a positive impact on performance, not just the existence of such an orientation per se (Zahra, 1993 and Dess et al., 1997) as quoted by Antonic and Hisrich (2004:521).

Entrepreneurial ventures are stereotyped as agile and capable of making decisions in real time. These time-compressed decision processes are created to meet the needs of customers, adapt to the environment, and compete in a continuously changing competitive landscape. Entrepreneurship is ultimately about creation and strategic management is about achieving above average performance via competitive advantage. It would be illogical to look at creation without looking at the outcome of such creation, whether its wealth creation, job creation, profitability or growth (Meyer et al., 2002:33).

Graetz (2002:457) points out that entrepreneurship is a creative, dynamic, responsive and often intuitive process within the framework of a largely un-predictive environment that fits more closely with the concept of strategic thinking.

\section{CORPORATE VENTURING AND THE STRATEGIC ENTREPRENEURIAL MINDSET}

According to Rose and Ito (2005:10), by adopting a strategy of spinning new businesses, companies create offspring that may be better adapted than the parent organisation for competing in a particular environment. This thinking and behaviour, which is similar to survival strategies in nature, are about strategic entrepreneurship.

The reproduction process deliberately creates offspring to compete in specific different niches where it provides new genetic material for the family. Synergies are created and expanded and adaptation becomes more likely when conditions change (Rose \& Ito, 2005).

This is supported by Michalski (2004:11) who emphasises that corporate ventures typically operate in emerging market environments where totally new resource combinations and competencies (entrepreneurship) are necessary and decisive for business success. Being independent of established corporate routines enables them to acquire and build up new resources and competencies much faster in such environments.

Eliasson and Davidson (2003:1) point out that corporate venturing can expand a firm's business by creating new products and entering new markets and that literature suggests that innovative firms that place higher emphasis on such activities tend to perform better than their less entrepreneurial ones.

\section{PROACTIVENESS, COMPETITIVE AGGRESSIVENESS AND THE STRATEGIC ENTREPRENEURIAL MINDSET}

Proactiveness is an opportunity seeking, forward looking perspective involving introducing new products or services ahead of the competition and acting in anticipation of future demand to create change and shape the environment (Kreiser et al., 2002:2).

Proactiveness (firm's response to market opportunities) is part of strategic entrepreneurial thinking in that it is all about a strong proactive tendency which gives a firm the ability to anticipate change or needs in the market place and be among the first to act on them. A strong competitive aggressive stance (response to competitive threats) gives a firm the ability to be a decisive player in a field of rivals and to act forcefully to secure or improve its position (Hitt et al., 2001:7).

According to Wickland and Shepherd (2005:74), proactiveness refers to a posture of anticipating and acting on future wants and needs in the market place thereby creating a first 
mover advantage. Proactive firms have the desire to be pioneers, thereby capitalising on emerging opportunities. In addition, risk taking proactiveness is associated with a willingness to commit more resources to projects where the cost of failure is high and also implies committing resources to projects where the outcomes are unknown. The company will be breaking away from the tried and true and venture into the unknown.

Hisrich and Peters (2002:47) state that proactive organisations are inclined to take risk by conducting experiments, taking initiative and are bold and aggressive in pursuing opportunities. They tend to lead rather than follow competitors in such key business areas as: introduction of new products and services; operating technologies; and administrative techniques.

Risk taking is a key element of the strategic entrepreneurial mindset.

The strategic entrepreneurial mindset imperative as a unitary construct that embodies "thinking" and "behaviour" is supported by literature. Without such a mindset, firms cannot compete in today's highly competitive environment where change is constant. There is a need therefore to cultivate the strategic entrepreneurial mindset.

\section{IMPLICATIONS}

The existence of a unitary construct calls for its recognition and practice. As a new concept, its appreciation and practice should be promoted and cultivated in all organisations. This is important bearing in mind the benefits that strategic entrepreneurial thinking brings. The importance and methods of developing the mindset are discussed below.

\section{Cultivating a Strategic Entrepreneurial Mindset.}

According to Nutt (2004:27), a key trap to non-strategic entrepreneurial behaviour is when decision makers promote a single idea, resulting in a limited search trap that reduces prospects of success. To generate a pool of ideas, the search for alternatives should be expanded by finding an arena where they use broad objectives and search from several perspectives.

Firms should create a climate where the whole organisation supports creative efforts, Amabile (1998:79), and should draw from their entire talent pool because the most effective strategic entrepreneurial actions sometimes surface from individuals or teams from whom such output wasn't anticipated (Kuratko \& Hornsby, 2001:60).

In addition, Williams (2004:187) emphasises that firms should promote divergent thinking, (the process of generating many and differing ideas as an important aspect of individual creativity) in organisations which will result in creative problem solving.

Aspects of opportunity recognition and exploitation are emphasised in Table 1. Opportunities lie in the external environment and ability to exploit lies within the organisation. Creation of an environment where strategic entrepreneurial thinking is nurtured is crucial to enable realisation of opportunities. 
Table 1: Cultivating a strategic entrepreneurial mindset

Nourish an entrepreneurial capacity

Encourage innovations that threaten the current business model

Encourage competitive aggressiveness as a mindset

Question the dominant logic

Link entrepreneurship and business strategy
The capacity for entrepreneurship can and should be deliberately developed within organisations. This imperative facilitates both the recognition and the exploitation of opportunity. Thinking ability can be imparted through training.

Disruptive innovations hold the promise of strategic renewal by potentially enabling the organisation to transition from less to more effective business models. This imperative primarily facilitates the exploitation of opportunity.

The opportunity "radar screen" must be explicitly defined for organisational members. This imperative primarily facilitates the recognition of opportunity.

Organisational strategic postures as well as key industry market assumptions must be periodically reviewed and tested to ascertain their validity. This enables proactivity to the competitive landscape and the primary facilitation of opportunity recognition.

Strategy should define appropriate arenas for planned innovations, yet autonomous inventions and discoveries must be capable of impacting the content of future strategy. This imperative primarily facilities the exploitation of opportunities.

\section{Adapted from: Covin and Slevin (2002:312).}

Rule and Irwin (1994:280) emphasise the need for the support of idea development and rewarding of strategic entrepreneurship. The idea generation and screening processes should be supported by real commitments of resources, time for exploration, and development.

This implies that everyone across the broad spectrum of the organisation should contribute to strategic entrepreneurial thinking for the organisation to be able to successfully relate to its environment.

\section{CONCLUSION}

The fact that strategy is about relating the organisation with its environment and entrepreneurship is about exploiting opportunities in the same environment shows how the psychological (thinking aspects) of these two aspects cannot be separated.

Strategic thinking is also about creativity and innovativeness. A firm competes by introducing new products and services and new methods or systems, in delivering or creating value. This encompasses the concept of entrepreneurship. A "combination" in thought processes and behaviour of strategic and entrepreneurial postures result in a strategic entrepreneurial mindset. The strategic entrepreneurial mindset is a unitary construct. This supports the proposition that strategic thinking is not different from entrepreneurial thinking.

As noted by Morris and Kuratko (2001:81), strategic actions provide the context within which entrepreneurial actions are pursued. As a result, the dynamic organisations of tomorrow will be ones that are capable of merging strategic actions with entrepreneurial actions on an ongoing basis. Strategic thinking focuses on achieving competitive advantage within a 
particular industry and market context, while entrepreneurship seeks to exploit opportunities others have missed or ones that have not been completely exploited. The actions are a result of the strategic entrepreneurial thinking, without which businesses cannot compete nor succeed.

Empirical research on whether there is a difference between strategic thinking and entrepreneurial thinking (the behaviour) and the doers (thinkers) is needed. The concept of strategic entrepreneurial thinking as a unitary construct needs empirical justification. Research which focuses specifically on the mindsets and not the overall topics of strategic management / planning and entrepreneurship needs to be pursued.

\section{REFERENCES}

Abraham S. 2005. Stretching strategic thinking. Strategy and Leadership, 33 (5):5-12.

Amabile TM. 1998. How to kill creativity. Harvard Business Review, Sept/October: 77-87.

Antonic B \& Hisrich RD. 2001. Intrapreneurship: construct refinement and cross cultural validation. Journal of Business Venturing, 10(1):495-527.

Antonic B \& Hisrich RD. 2003. Clarifying the intrapreneurship concept. Journal of Small Business and Enterprise Development, 10(1):7-24.

Antonic B \& Hisrich RD. 2004. Corporate entrepreneurship contingencies and organizational wealth creation. Journal of Management Development, 23(6):518-550.

Bonn I. 2001. Developing strategic thinking as a core competency. Management Decision, 39(1):63-70.

Bonn I. 2005. Improving strategic thinking: A multilevel approach. Leadership and Organization Development Journal, 26(5):336-354.

Bouchard V. 2001. Exploring Corporate Entrepreneurship: A corporate Strategy Perspective. European Entrepreneurial Learning, 2001(12).

Covin,JG \& Slevin DP. 2002. Entrepreneurial Imperatives of leadership in Hitt, Ireland, Camp \& Sexton. Strategic Entrepreneurship: Creating a new mindset. $1^{\text {st }}$ Ed. Oxford: Blackwell.

Eliasson C \& Davidson P. 2003. Entrepreneurial management, corporate venturing and financial performance [Online] Available from: http://www.babson.edu/entrep/fer/BABSON2003/XIX/XIX-P1/xix-P1.htm [Accessed: 29/04/2006]

Eliasson C, Wikland J \& Davison P. 2002. Entrepreneurial management and Schumpeterian resource combination [Online] Available from: http://www.babson.edu/entrep/fer/BABSON2002/X/X_P1/P1/HTML/x-p1.htm [Accessed: 07/04/ 2006].

Fink A, Marr B, Siebe A \& Kuhle JP. 2005. The future score card: Combining external and internal scenarios to create strategic foresight. Management Decision, 43(3):360-381.

Graetz F. 2002. Strategic thinking versus strategic planning: towards understanding the complimentaries. Management Decision, 45(5):456-462.

Hisrisch RD \& Peters MP. 2002. Entrepreneurship. $5^{\text {th }}$ Ed. New York: McGraw -Hill / Irwin.

Hitt MA, Ireland RD, Camp SM \& Sexton DL. 2002. Strategic Entrepreneurship: Creating a new mindset. $1^{\text {st }}$ Ed. Oxford: Blackwell. 
Kelly D, Neck HM, O'Connor GC \& Paulson A. 2002. Developing radical innovation capabilities: Opposing forces from corporate entrepreneurship and organizational systems [Online] Available from:

http://www.babson.edu/entrep/fer/BABSON2002/XV11/XV11_P1/P1/html/xvii-p1.htm [Accessed: 08/05/2006].

Kuratko DF \& Hornsby JS. 2001: Corporate entrepreneurship and Middle Managers: A model for corporate entrepreneurial Behaviour [Online] Available from: www.usabe.org/knowledge/proceedings/2001/038.pdf [Accessed: 11/2005].

Kreiser P, Marino L \& Weaver KM. 2002. Assessing the relationship between entrepreneurial orientation, the external environment and firm performance [Online] Available from: http://www/babson.edu/entrep/fer/BABSON2002/X/X/-p3/p3/html/x-p3.htm [Accessed: 10/04/2006].

Lewis PS, Goodman SH \& Fandt PM. 2001. Management challenges in the $21^{\text {st }}$ century. $3^{\text {rd }}$ Ed. South Western College.

Masifern E \& Vila J. 1998. Interconnected mindsets: Strategic thinking and the strategy concept, in Hitt, Ricart, Costa \& Nixon. New managerial mindsets, organisational transformation and strategy implementation. Chichester: John Wiley \& sons.

Mcgrath RG \& MacMillan I. 2000. The entrepreneurial mindset: Strategies for continuously creating opportunity in an age of uncertainty. Boston: Harvard Business School.

Meyer GD \& Heppard KA. 2000. Entrepreneurship as strategy: Competing on the entrepreneurial edge. Thousand Oaks: Sage.

Meyer GD, Neck HM \& Meeks MD. 2002. The entrepreneurship, strategic management interface in Hitt M.A, Ireland, R.D, Camp, S.M, Sexton, D.L. Strategic Entrepreneurship: Creating a new mindset. $1^{\text {st }}$ Edition. Oxford.Blackwell.

Michalski T. 2000. Radical innovation through corporate entrepreneurship from a competence-based strategic management perspective. International Journal of Management, 2(1):22-41.

Mintzberg H, Ahlstrand B \& Lampel J. 1998. Strategy safari. A guided tour through the wilds of strategic management. New York: The Free Press.

Morris MH \& Kuratko DF. 2002. Corporate Entrepreneurship: Entrepreneurial development within Organisations. London: Thompson South Western.

Nutt PC. 2004. Expanding the search for alternatives during strategic decision making. Academy of Management Executive, 18(4).

O' Gorman C. 2001. The sustainability of growth in small and medium sized enterprises. International Journal of entrepreneurial Behaviour and Research, 7(2):60-75.

Rose EL \& Ito K. 2005. Widening the family Circle: Spin offs in the Japanese Service. Long Range Planning: 38(1):9-26.

Rule EG \& Irwin DW. 1994. Fostering Entrepreneurship, in Jennings Multiple perspectives of Entrepreneurship: Text, Readings and cases. Cincinnati.

Senge RD. 1996. The Fifth Discipline. Sydney: Random House.

Sathe V. 2003: Corporate Entrepreneurship: Top managers and new business creation. $1^{\text {st }}$ Ed. Cambridge: Cambridge University. 
Schendel DE. 1995.Strategy futures: What's left to worry about? Advances in Strategic Management, 11B:143-188.

Slater SF \& Oslon EM. 2000. Strategy type and performance. Strategic Management Journal, 21:813-829.

Skrt B \& Antonic B. 2004 Strategic Planning and Small firm Growth. An empirical examination. Managing Global Transitions, 2(2):107-122.

Thompson JL. 2004. The facets of the entrepreneur: Identifying entrepreneurial potential. Management Decision, 42(2):243-258.

Wickland J \& Shepherd D. 2005. Entrepreneurial orientation and small business performance: a configurational approach. Journal of Business Venturing, 20(1):71-91.

Williams SD. 2004. Personality, attitude, and leader influences on divergent thinking and creativity in organizations. European Journal of innovation Management, 7(3):187-204.

Wright M, Hoskisson RE \& Busenitz LW. 2001. Firm rebirth: Buyouts as facilitators of strategic growth and entrepreneurship. The Academy of Management Executive, 15(1):111.

Wunderer R. 2001: Employees as "co- intrapreneurs" - a transformation concept. Leadership and Organisation Development Journal, 22(5):193-211.

Zahra SA \& Bogner WC. 2000. Technology strategy and software new venture performance: Exploring the moderating effect of the competitive environment. Journal of Business Venturing, 15(2):135 -173.

Zhao F. 2005. Exploring the synergy between entrepreneurship and innovation. International Journal of Entrepreneurial Behaviour and Research, 11(1):2. 